\title{
Ethnography, Cartography, Ethnomapping: dialogues and compositions in the field of research
}

Maria Teresa Nobre. Universidade Federal do Rio Grande do Norte

Ana Karenina Arraes Amorim. Universidade Federal do Rio Grande do Norte

Simone Frangella. Instituto de Ciências Sociais da Universidade de Lisboa - ICS/UL

\begin{abstract}
From research experiences with homeless people, we seek to discuss the possibilities and challenges of the ethnographic and cartographic method, as they have been used in anthropology and psychology, from the perspective of interdisciplinary dialogues and compositions. The precarious living conditions of people on the street, who hang between exclusion and resistance, continually challenged us and imposed reflections on the relations between the researcher, the participants and the institutions in the research field. In this article, we present the premises of a methodological composition that we call "ethnocartographing" in an ethical and political dialogue about the act of research as an affirmation of life. We emphasize that the proposed approach does not translate into methodological techniques, but corresponds to an immersion into the universe of the other in which writing constitutes an important dimension of knowledge production between research and life.
\end{abstract}

Keywords: research methods; ethnography; cartography; homeless population; vulnerability.

\section{Resumo}

Etnografia, cartografia, etnocartografar: diálogos e composições no campo da pesquisa. A partir de experiências de pesquisas junto a pessoas em situação de rua, buscamos discutir as possibilidades e desafios do método etnográfico e do método cartográfico, como têm sido utilizados na Antropologia e na Psicologia, numa perspectiva de diálogos e composições interdisciplinares. A condição de vida precária das pessoas na rua, que pendulam entre a exclusão e a resistência, nos interpelou continuamente e impôs reflexões acerca das relações entre o/a pesquisador/a, os participantes e as instituições no campo da pesquisa. Neste artigo, apresentamos as premissas de uma composição metodológica a que chamamos de "etnocartografar", num diálogo ético e político sobre o ato de pesquisar como afirmação da vida. Ressaltamos que a abordagem proposta não se traduz em técnicas metodológicas, mas corresponde a uma incursão no universo do outro em que a escrita constitui uma importante dimensão da produção de conhecimento entre a pesquisa e a vida.

Palavras-chave: métodos de pesquisa; etnografia; cartografia; população de rua; vulnerabilidade.

\section{Resumen}

Etnografía, cartografía, etnocartografar: diálogos y composiciones en el campo de la investigación. A partir de experiencias de investigaciones junto a personas sin vivienda, discutimos las posibilidades y desafíos del método etnográfico y del método cartográfico, como ha sido utilizado en la Antropología y la Psicología, en una perspectiva de diálogos y composiciones interdisciplinares. La condición de vida precaria de las personas sin vivienda, que se mueven entre la exclusión y la resistencia, nos interpeló continuamente e impuso reflexiones acerca de las relaciones entre el investigador/a, los participantes y las instituciones en el campo de la investigación. En ese artículo presentamos las premisas de una composición metodológica a la que llamamos "etnocartografar", en un diálogo ético y político sobre el acto de investigar como afirmación de la vida. Resaltamos que los enfoques no se traducen en técnicas metodológicas, pero corresponde a experiencias de incursión en el universo del otro en que la escritura constituye una importante dimensión de la producción de conocimiento entre la investigación y la vida. Palabras clave: métodos de investigación; etnografía; cartografía; sin vivienda; Vulnerabilidad. 
In the field of the humanities and social sciences, we often come across subjects that challenge us, both in terms of how to approach subjects and objects that we select or encounter in fieldwork, as well as the possibilities of recording and analyzing the data collected. It often follows that research work is linked to practice, such as action research, intervention research, or other "situation research" modalities (Lapassade, 2005). These challenges are accentuated when it comes, for example, to research on "vulnerable subjects" (in situations of extreme poverty, social suffering, violence, rights violations and exposure to imminent risks); "dangerous topics" (drug, human and arms trafficking, slave labor, prison systems, extermination groups, militias, and contract killings); emerging topics or fields (new labor relations, new family arrangements, migratory phenomena, body production, abnormal sexualities and other gender-based issues in their interfaces with class, race, religion, etc.); and collectives or movements of resistance to the instituted powers (social movements, collective confrontation with the State, etc.).

In these and other research situations, the method guides paths of investigation, regarding the theoretical-methodological options and ethical behavior of the researcher. Far from being the application of data collection and analysis procedures, the method is defined by theoretical frameworks and political options around the choices about "what" and "how" to research, which define this trajectory a priori, especially when "the life of others" is the focus of our work. According to Corazza (2007, p. 121), "the choice of a research method, involves how we were and are subjective, how we participate in the game of knowledge and how we relate to power". This becomes particularly evident when we take as our object "precarious lives", those defined by Butler (2015) as unrecognized as "living" - and therefore killable or disposable - according to certain epistemological principles and normative schemes defined by significant power struggles that disqualify them as such. In this sense, the author considers life as a political analysis category, in a reappropriation of Michel Foucault (2005) in his theory of biopower and biopolitics.

Understood as the act of governing and controlling not only individuals but the population, biopolitics is the exercise of life management and its multiple needs through technologies, guidelines and political action. This governmentality goes beyond the notion of discipline (centered on the individual) and the dichotomous relationship between state and society and is configured as the political economy of life in general, through which power spreads and takes on a microphysical dimension (Foucault, 1981/2006). However, if biopolitics invests life with power, it too is invested with power and, therefore, the place where a counterpower and resistance emerges. When discussing the relationship between power and freedom, Foucault states that resistance as inseparable from this relationship and concludes that analyzing these issues marks the transition from the political to the ethical (Revel, 2005, p. 28).

When considering these assumptions in research production, body education is needed to construct other ways of seeing and expressing what power formations tend to make invisible and silent. Particular interest in these "precarious lives" emerges in their immanence to the production of knowledge as a necessary means of facing life's challenges, in the contexts of a globalized capitalist world where life itself is deemed a commodity.

By accepting the challenge to research the immanence of living, we understand that the work is produced from the experience of following these lives in the scenarios we find ourselves in as researchers and where we live the events. It is about doing improvised research, in that relational place where what matters is "becoming another" (Simoni \& Mosschen, 2012): conducting research with others and not about them, radicalizing the encounter with differences. From this perspective, the act of researching requires one to work in the present of those who are implicated with reality, which also demands a search for what produces the difference in the "effective history" of things (Foucault, 1981/2006). In this sense, we consider research involved with life as "a way of thinking, feeling, desiring, loving, hating; a way of interrogating, provoking events, exercising the capacity for resistance and submission to control"(Corazza, 2007, p. 121). Thus, research is implicated in our own lives and marks our political choices and ethical positions.

Analysis of the implication of the challenges posed by the research indicates the need to adopt a way of thinking characterized by epistemological humility, the search for useful tools to understand the world and abandoning the idea of pursuing the truth from a privileged position through which we can definitively understand the world and the relationships that surround us (Veiga-Neto, 1995).

The exercise of making changes, suspecting that what is given and accepted as natural and true, is necessary. These are naturalizations that reproduce themselves and often make us exert a hierarchical power towards the "other", which is the object of our investigation. 
Given the wide range of research methods in the social and human sciences, we underscore ethnography and cartography as unique ways of producing knowledge that meet the aforementioned conditions. For the purpose of this article, we consider the dialogues and compositions that we established between them, with respect to immersion in the field (ethnographic perspective), as well as the ways of following the processes experienced there (cartographic perspective) and in the writing, reading and analysis of data and events (procedures located "between" cartography and ethnography). We will call the construction of this territory of political, ethical and aesthetic experimentation, ethnocartographing (Vasconcelos, Melo, \& Souza Neto, 2018), underscoring that we are interested in this trajectory to point out possibilities and challenges of research in affirming life, especially "precarious lives" in contexts of vulnerability. To avoid associating vulnerability with victimization we consulted Castel (1997, p. 19) for whom vulnerability is produced by disaffiliation, an effect of the "combination of precarious work and the fragility of relational supports", which shape the social isolation of individuals and groups and subject them to chronic instability. This combination exposes them to serious risks, making vulnerability and risk inseparable concepts.

The notion of ethnocartography is not recent in the field of human and social sciences. According to Castro and Castro (2017) between 1920 and 1970, it was linked to cultural cartography and visual projection, especially focused on the production of maps of ethnic spaces, and later, under the influence of ethnomethodology, the intersubjective projection of the use of space and the space-environment behavior of traditional populations. The authors, in turn, understand ethnocartography from the phenomenological perspective, in terms of the relationship of the person with space, where interaction, experience and attribution of meaning are key. The notion of ethnocartography has also been used in geographic and anthropological research with a number of ethnic groups in the production of maps of historical and cultural elements of these populations (Bittencourt, 2011), as in social cartography.

The ethnocartography discussed here is different. It combines ethnography, the main anthropological field research method, with cartography, proposed by Gilles Deleuze and Félix Guattari to study subjectivity (Kastrup, 2007; Passos, Kastrup, \& Escóssia, 2009), as presented by Bittencourt (2011). In his doctoral thesis, the author systematizes the assumptions and techniques of conducting ethnocartography, in a composition between the approach and description of the field in ethnographic research and the movements of desire present therein, the lines of force, intensities and feelings that permeate it, as described by schizoanalysis. Here we affirm these assumptions with some additions, given the specifics of our work, emphasizing the experimentation of this practice.

The article is divided into four sections, the first being a description of the research field, and the following two a discussion about the ethnographic method, the cartographic method and the compositions between them, based on research experiences of the first two authors in a study of the homeless population in the city of Natal, capital of Rio Grande do Norte state, Brazil. The fourth section discusses the challenges of writing about fieldwork, a speech made by the third author based on her work with the homeless in São Paulo (Frangella, 2010) ${ }^{1}$.

\section{The research field}

Getting to know the homeless population in Natal was the task facing us as professors / researchers and members of the Human Rights Reference Center of University Federal of Rio Grande do Norte (CRDH/ UFRN), under the leadership of the local chapter of the National Movement for Street People (MNPR/ RN), in 2013. The proposal of this social movement was to use this knowledge to contribute to public policies for this population. At that time, there was an overnight municipal shelter for the homeless, a reference center specialized in social assistance (Pop Center) and three homeless assistance teams belonging to the National Health System's (SUS) basic care network.

In addition to the dearth of homeless services, from a quantitative standpoint, there were also problems regarding the type of care, marked by prejudice and stigmatization, and no projects that promoted alternatives to life on the street for those who so desired. The situation underscored the gap between what was prescribed in the National Homeless Policy, established by Decree-Law 9.057/2009 (Decreto n. $7.053 / 2009,2009)^{2}$, and what in fact had been implemented. Thus, the tensions inherent in the institutionalization processes (Lourau, 1993) were evidenced by the contradiction between the instituting dimension - the advancement of the social struggles of this population that prompted the creation of a specific public policy -

Estudos de Psicologia, 24(1), janeiro a março de 2019, 54-64 
and the instituted dimension, mired in the institutional practices of public services created to set it in motion.

The leaders of the social movement believed that knowing this public better would be a strategy to pressure the state to expand and qualify the service network and its professionals.

After analyzing the task put before us, from the theoretical-methodological perspective of institutional analysis (Lourau, 1993), we conducted intervention research between 2013 and 2016 (Rocha \& Aguiar, 2003), aimed at characterizing the sociodemographic and psychosocial profile of this population, mapping the formal and informal care and support networks and obtaining their life histories ${ }^{3}$, while seeking to contribute to their struggles against the state.

Between 2015 and 2018 we carried out a new study to ascertain how homeless people lived, with emphasis on their daily routine and the resistance practices of those who make the streets a space to produce material and symbolic existence. We were interested in obtaining more detailed knowledge of these people outside institutional spaces, in the streets, in their daily activities, ways of living, eating, sleeping, working, peer relationships, conflicts, affective bonds, and their interactions with the city. How they coped with the countless adversities they faced on a daily basis and what answers they produced in order to break their subjugation and victimization, (re) inventing themselves and the world around them, were the guiding questions of the research.

A third study was conducted between 2016 and 2018, in order to determine the care demands, the characteristics of homeless drug and alcohol abusers in contexts of vulnerability, treated or not by the Psychosocial Care Network (RAPS) and the institutional itineraries of these individuals in the search for care and social support. This study was motivated by the fact that earlier research had constantly encountered problems associated with substance abuse, with serious effects on the health and affective, social and political relationships of these users and the absence/ fragility of a public care network for these people.

In this article we will not discuss the results of previously published articles (Amorim, Nobre, Coutinho, \& Gomes, 2017; Nobre, Moreno, Amorim, $\&$ Souza, 2018). Our intention here is to discuss the working method, which notwithstanding the singularities of the objects and objectives of each study, was guided by ethnography and cartography.
In all of the studies conducted, fieldwork consisted of meeting people on location, without creating special conditions to interview them or recording the interviews or conversations, due to the inherent insecurities and suspicions of the homeless. Thus, we spoke to them at the entrance of the municipal shelter, while they waited for it to open at night; on the traffic island where they lived; in squares where they talked or worked; at the soup kitchen during breakfast, in a downtown square and an evangelical church; on the sidewalk in front of the Metropolitan Cathedral, where soup was served every day; on storefronts where they slept. During breakfast, the participant observation technique was used, where the researchers acted as volunteers, albeit making it clear to the institutions and users that research was being conducted. Participant observation was also the methodological resource used in the MNPR / RN policy forming spaces, meetings, forums, seminars and workshops, in our capacity as members of the CRDH / UFRN and/or university extension projects and curricular stages, occasions where we could record spontaneous statements from people. Finally, we used walks around the city - which we call itinerant observation - in different neighborhoods, days and times, when we could directly observe and monitor events and talk informally with people.

Thus, based on field diaries, interviews, narratives and statements, participant and itinerant observations and the study of documents, we sought to incorporate the field, not with the intention of elucidating its complexity, but trying multiple and exhaustive possibilities to achieve our objective using different procedures so that we could visualize its multidimensionality.

\section{Ethnography and the processes of immersion and knowledge in the field}

Insertion into an ethnography-based research field assumes that researchers participate, for a significant period of time, in the lives of the people and groups they are studying, which allows them to dissociate themselves from producing abstract and speculative knowledge, constructing it from the relationship between the observer and the observed.

Thus, they must be accepted and acknowledged in the field and to be close to those whose lifestyles, practices and customs they intend to investigate. This means experiencing it "up close and inside" (Magnani, 2002), immersing oneself, dwelling on what one sees and hears, being aware and inattentive at the same time, approaching 
the unexpected and unpredictable (Laplantine, 2004) and the imponderables of the field (Malinowsky, 1978), so that it guides our involvement, the sequence of the steps to take, and the path to follow.

"Ethnographic research is actually a "perception" and "knowing", involving a new relationship with the sensitive" (Idelfonse, 2013, p. 15), in which not only events, but everything that affects the senses should be recorded and analyzed. According to the author, it is important to be affected by the intensities of the field, to avoid the risk of not understanding the singularities of an unknown way of life and "translating" it from one's own prejudices and naturalizations. Therefore, it is also necessary to exercise strangeness and denaturalization, which means having the ethical and political attitude of suspecting, distrusting and casting doubt on the naturalness of facts, objects and practices, as well as apparent truisms (Prado, 2012). This process, which considers the impacts produced by the field on the researchers themselves, has a transforming effect, an aspect widely discussed by Lévi-Strauss (1955/1996) and Merleau-Ponty (1960/1980). In fact, the effects in the field and not being able to leave these experiments in the same way as it we entered them were a striking feature of our work, although at no time was this dimension referred to as an interiority, but to the way we were objectified by the experiences in the field and how this process produced other subjectivations

Although we do not work with strict protocols for data entry, we must pay attention to the rigor of ethnographic research in the construction of open knowledge. Ethnography is not an impromptu or spontaneous practice, but depends on how the field itself conducts research, which concerns not only the methodological procedures, but the quality of the relationships built therein (Sato \& Souza, 2001).

Participant observation, an essential feature of ethnographic research, was central to our fieldwork and allowed us to experience it intensely. Weekly visits to the field, one to three times a week during these years, allowed us to share experiences and get to know people's ways of thinking, feeling, talking and living, as well as the meaning they give to their practices. In these contexts, we were part of the field and we shared people's experiences of pain, abandonment, neglect, and revolt, but also moments of joy, relaxation, achievement, in which the astute tactics invented in everyday life stood out (Certeau, 1984/2005). We were able not only to "observe" ordinary and extraordinary life situations, but also be part of them.

Walking around the city was also an important methodological strategy, which enabled an approximation of ways of life on the street through images, sensations and affective, cognitive and body experiences, less linked to the subjects' discourse. The long walks at various times of the day, with or without an established route, put us in contact with the hitherto unknown or unsuspected practices of homeless people, especially regarding their ways of living, the uses of their body, and their human-nonhuman relationships (places, discar$\mathrm{ded} /$ recycled objects and animals). This encounter with diversity is only possible if we wander slowly around the city, discovering the strangeness and surprises that it conceals, and being open to haphazard encounters (Fortuna, 2018). These experiences involve segregation and intolerance, and extremely precarious lifestyles, but also with the solidarity and inventiveness that make up the multiplicities observed on these itinerant paths.

\section{Cartography as a method in the immanence of life}

Cartography, as proposed by Deleuze and Guattari, is a way of conceiving research and the researchers' encounter with their field, being understood as a method, but not "as a synonym of intellectual discipline, defense of rationality or systematic rigor to say what is and is not science, as propagated by the modern paradigm" (Romagnoli, 2009, p. 169).

From the cartographic standpoint of doing research, reality is learned by the bias of immanence to life and the externality of thought, by integrating subjective, social, biological, cultural and economic lines.

Life flows are actually changeable and connective, but also coded, segmented and reterritorialized, not belonging to a single individual or social group. Thus, each researcher and object of study inhabit a context, share ways of relating and constitute existential territories, in their traits, connections and experiences, which must be mapped in cartography, in order to know reality in all its complexity (Romagnoli, 2009).

By combining research and life in all its complexity, cartography is based on the assumption that knowledge is process and inseparable from the movement of life itself and the feelings that accompany it, involving the researchers' creations and implications, thereby producing deterritorialization in the field of science. (Mairesse, 2003). 
As such, the cartographic method imposes a number of demands.

The first concerns an ethical-aesthetic-political stance of embracing life in its expanding/ inventing and capturing movements that occur during encounters in the field and demand care and prudence. Care is characterized by being welcoming and attentively listening to the actors and experiences we are exposed to in the field of investigation and by the analytical and critical disposition regarding life, sustained by the willingness to find the knowledge of the other. Prudence is needed when developing relationships that enhance the construction of knowledge about life, paying special attention to biopolitical elements. Thus, in conjunction with the homeless people, we produced the conditions that allowed life-affirming encounters for each of them, including their knowledge and daily challenges, with the willingness to meet existing care demands, building interferences in health care institutions and services, in order to assert their rights, while accompanying each one's inventions and practices to proclaim their own lives.

A second condition can therefore be deduced: cartography is always intervention research (Passos, Kastrup, \& Escóssia, 2009; Rocha \& Aguiar, 2003). Conducted in conjunction with the research participants, intervention research focuses on the procedural change of the object through interventions in the daily spaces where it takes place. According to Coimbra (1995), there is a change in the conception of doing research where the so-called "know to transform" is replaced by "transform to know", illustrating the inseparability between knowledge and transformation. The change in the context of intervention research occurs through the denaturalization of practices, constantly analyzing the research institution itself, thereby producing a non-dichotomous relationship between theory and practice, subject and object, exposing the entanglements of power networks and interests in the composition of the investigative field (Rocha \& Aguiar, 2003). Thus, when meeting people, the demands imposed on us required the analytical task of thinking about our place in institutions. Our meetings with the participants aimed to bring the "languages" closer together, create a common plan and produce analytical space with them in order to map the power games, the possibilities of producing resistance and interference in the ruling power about the ways of being homeless, prejudices, impossibilities, and gross inequalities, as discussed in cartographic research by Félix, Sales and Soares (2016).
The third condition is the development of "lurking attention" (Deleuze, 2003), which concerns the functioning of attention, not as a focus to represent objects, but as a function to detect signs and circulating forces. In other words, the cartographer's attention creates "territories of observation" (Kastrup, 2007) and recognizes what exists as a potential that is updated in research meetings. Thus, in the field, we hear the different voices, are aware of gestures and events, but not in their linearity and chronology. The senses operate in that which moves, silences, breaks out and is on the sidelines. In meetings with homeless people, for example, it was the gestures, attitudes of one or the other, "offstage," and unpretentious phrases that often incited us to look and analyze, as did the silences and absences.

Thus, we are aware of experiences as "events" in the emergence of singularities. Breaks occur in the field, streams of forces ask for passage. We seek to be "on the lookout" for events as a "relationship of forces which is reversed, a confiscated power, (...) a domination which weakens, relaxes and poisons itself, a masked other which makes an entrance" (Foucault, 1981/2006, p. 28).

In working with this population, we were prompted to become another, so as to "wish" what was happening to us and consider it as something inevitable.

The possible and real annoyances with these people concerned several different things: unpleasant smells, words and expressions that required translation, frequent requests for financial aid, among others. Each of these things are part of the formation of "sensitive others" who make meetings possible, making us worthy of them and transforming ourselves. As suggested by Deleuze (2003, p. 152):

The event is not what happens (accident), in it occurs the pure expression that gives us a sign and waits for us. (...). It is what must be understood, what must be desired, what must be represented in what happens. (...) Nothing else can be said, nothing else has ever been said: to become worthy of what happens to us, therefore, to want and capture the event, to become the child of one's own events and to be spiritually reborn, thereby, breaking with one's flesh birth.

These other births took effect in the field and demanded significance. In our experience, the overflow that events produced called for reflection, words, and thought. The research movement was being called upon to "weaken certain dominations" as Foucault (1981/2006) tells us and to construct a "becoming another" as proposed by Deleuze (2003). 
Among the authors who discuss the approximation between ethnography and cartography, we underscore the contributions of Barros and Kastrup (2009), who point out the following as meeting points between both: the experience of insertion into the research field, the direct contact with people and their existential territory, participation in fieldwork life - when researchers change and are changed by it -, the coexistence with subjects in an affective and trusting relationship between researchers and the researched. The authors also emphasize: the experience that the strangeness of what is familiar produces (inherent to ethnography) and approach the concept of agency, of composition between the heterogeneous, (inherent to cartography) which the anthropologist Janice Caiafa calls "sympathy" between "natives" and researchers, as a composition of bodies involving mutual affection (Caiafa, as cited in Barros \& Kastrup, 2009, p. 57). Finally, they highlight the modes of recording field experiences in a research diary as points of convergence between them.

Despite discussing bringing these two methods together, the authors address ethnography and cartography in their interfaces. This perspective was also adopted here. In our research we do not intend to nullify the differences between these methods, but to appropriate them through dialogues and compositions, from the way we were affected by the field and what it calls us to do, at different times. It consists therefore, of variable and flexible compositions, driven by movements guided by the field itself, which blur borders without nullifying them.

From an ethical standpoint, based on the operationalization of fieldwork and its development as intervention research, experience often placed us in two situations, as follows: we were simultaneously in a field which we belonged to and implicated us through academic, political and militant practice, since the field of research was also our field of action as defenders of human rights. On the other hand, fieldwork, especially that performed through participant and itinerant observation, put us in touch with the unknown, the vicissitudes and singularities of practices, the surprising uses of the city, producing intense feelings: closeness-strangeness, known-unknown, near-far, in-out. It was necessary to bet on the "between" of these things, a task made possible by the dialogue and compositions between ethnography and cartography, whose dynamics proved to be capable of many arrangements, in a kaleidoscope of different images, movements and shapes. In this respect, we recognize the necessary composition of ethnocartographing: while ethnography allows us a greater, more intense and more "lived" field approach, its more detailed description and the meanings attributed by the subjects to their practices, cartography helped us follow the movements and processes, map the lines of force, the flows and feelings, knowing-intervening and intervening-knowing.

The possibility of jointly adopting the principles of the ethnographic and cartographic method was presented in operations where they were indissociable, such as the practices of: a) allowing themselves to be immersed in the field, open to chance encounters; b) following intensities, flows, processes and movements in the field, and the desires and feelings produced; c) experiencing the field through prolonged and continuous presence, participant observation, itinerant observation and intervention research; d) mapping the hard, moving and escape lines that constitute the field; e) considering the inseparability between research and life, which adds feelings to knowledge production.

These practical research guidelines that we have formulated so far from our experiences can be further developed, deepened and transformed into other investigations and experiences. However, it seems to us that an essential element in our concerns, the exercise of which has enabled us to arrive at these formulations, refers to the emblematic, crucial and difficult task of "writing" to which we dedicate the interface of these places we occupy, as discussed below.

\section{Shared textures and worlds}

As part of a dialogical proposal around homeless people and the knowledge production process described, we propose a reflection on this stage after the methodological process of ethnocartography, a crucial step that finalizes this incursion into the field. Neither ethnographic nor cartographic approaches translate only into methodological techniques, but rather are experiences of incursion into the other's universe, in a co-presence relationship, in the co-sharing of time (Fabian, 2014). In an exercise of togetherness, research subjects and researchers are aware of the world (Kastrup, 2007; Pina-Cabral, 2013, p. 261). Writing constitutes a second dimension of knowledge production based on bridges between different worlds (Fabian, 2014; Passos \& Benevides, 2009). 
The writing that derives from these experiences has a specific temporality in order to reposition the field experience. It is a descriptive, documentary, analytical instrument that provokes reflections that purify and discuss this incursion, which presumes a meeting between previously codified knowledge, but constantly challenged by the new knowledge that immersion in the studied context engenders. It is a second zone of experimentation in which, in addition to mapping and investigating field events, questions expand beyond the shared-researched universe. Far from being synonymous with data recording, describing what was seen while "there", the writing that results from the process of ethnocartography, carries with it the essential communicative dimension that occurs between the researcher and the subject researched, starting from the "context of the situation", and revealing the multiple meanings of social encounters (Barros \& Kastrup, 2009; Peirano, 2002, p. 11), opening the way to a communicative, sensory, almost tactile dimension.

The encounters, voices, and field movements are conveyed in writing through our observations in an engagement with the world. Writing is part of the process of immersion from the field period through the field notes and initial reflections we put on paper. In both instances, it is always an opening for the researcher's communicative intentions (Passos \& Benevides, 2009; Pina-Cabral, 2013). This practice, however, has different weights in each of these steps. If, at first, it is an essential auxiliary instrument for researchers in the elaboration of what they see, feel, experience, in the next step it will be the artifact that provides the bridges between the studied universe, the researchers' critical reflection and the literature that challenges them. The production of this knowledge is based on an ambivalence of immersion in the researched universe; it is totally involved and committed to learning the universe of relationships of the subjects in assimilating their universe of relationships, and partially in the next stage of writing, when we address the effects of this encounter with the different perspectives in the world (Lima, 2013). At this point, the commitment to sensitively and faithfully convey what we have seen and experienced is challenged and repositioned.

Mutuality arising from ethnographic or cartographic positioning is necessarily implicated in the written text. However, it is worth remembering that this world of sharing is not a world of univocal meanings. Field research is not necessarily comfortable and we do not necessarily agree with the subjects we work with (Fabian, 2014; Ingold, 2014; Pina-Cabral, 2013). The proposal to produce knowledge based on communicative interaction is not easy, does not claim to be objective, is not necessarily the result of cooperation. However, this fundamental communicative experience permeates the field and writing is an epistemological condition necessary for producing the intended knowledge. To that end, we assume that participant observation can be seen as an ontological commitment with critical implications (Ingold, 2014) and presumes intersubjectivity that must be achieved (Fabian, 2014).

Writing is not a simple transposition from the field to text. Although the field immersion period and the text are correlated and subsequent steps, they are in themselves different modes of integration (Lima, 2013). According to Sanjek (1996), what we learn in the field are local theories of meaning, which challenge the theoretical universe hitherto constructed. Ethnographic and cartographic data dialogue, contest or expand previous theories, making the dimension experienced in the field a means of accessing worldviews (Peirano, 2002; Romagnolli, 2009).

Writing assumes a rearrangement of the stories, events and narratives experienced in the field in a text that opens up to other speakers and produces an imaginative and speculative recreation of the effects of fieldwork (Lima, 2013). This speculative exercise is related to the possibilities of the human condition in the world (Ingold, 2014). Writing is the time to value immersion in itself (that is, coproduction of the outlooks, the value of relationships over information), while at the same time bringing information to the forefront. As suggested by Lima (2013, p. 22), it is the moment to "integrate what has already been analyzed at the moment of observation to that observed at the moment of analysis".

When we turn to subjects in vulnerable situations, directly affected by or resisting exclusionary power practices, what are the possibilities of communicating our encounter with them, the complexities of learning about their world, the effects of our presence on the field?

How can we ponder their wounds and their setbacks, without making them oblivious to objectification but also without victimizing them, to the point that we do not understand their agencies and their world dynamics? These are some of the questions faced by researchers who enter these universes, such as the street world. The vulnerability and disconcerting steps of the homeless create the challenge of simultaneously 
condensing and complexifying the fragmentation and intensity of their daily lives, exposed to clashes with institutions, radical deprivation and constant stigmatization.

The socioeconomic conditions, impositions of the urbanistic power and daily and tactical ways of reacting to this oppressive picture define the condition of these subjects in a precarious corporeality. They inhabit an unthinkable place of the streets, opposing the ideologization of the urban landscape. This results in a perverse process of dispossession, material and symbolic subtraction (Frangella, 2010), on the one hand, and the creation of new forms and spaces of experience, of territorial and political inventiveness constituted by them from the very process of exclusion, for example, on the other (Rui, 2014). Engaging in the processes of gross exclusion and the surprising forms of political agency and resilience permanently disconcert; they question us in our own conditions of existence. By being in a relationship of involvement with homeless people, either through the mutual relations that are built in ethnographic practice or by opening the senses to the hard, mobile and escaping lines that the cartographic approach allows, one is constantly dealing with instances of precariousness that underlie the relationship these people have with the space in which they live.

A story that keeps a temporal update on an emotional and physical experience - violence, for example - that never ceases and therefore returns to feelings and events helps us "identify ways to build other recommendations to the world, that is, other possibilities for the future, but also for memory " (Monroy, 2015, p. 26). Gestures, words, and silence need to be contemplated in ethnographic, cartographic or even ethnocartographic writing, as we are sensitively proposing, mapping the researcher in listening to the narrated landscape, the expressions of the researched subjects, while simultaneously providing a broad picture of the context that the reader can access, without failing to sensorially and reflexively grasp the social and personal life in this context. As a consequence, the artisanal exercise that results from ethnographic and cartographic immersions allows us to rethink experiences and transformations triggered by the researcher and shared with other shared worlds.

\section{Final considerations}

We sought to present possibilities of compositions between the ethnographic and cartographic method, from experiences with the homeless population. The precarious living condition of these wanderers, who hover between exclusion and resistance, continually challenged us and imposed reflections on the relationships between the researcher and the subject in the research field. Dealing with this precariousness and being aware of the unique forms of exclusion and coping with this condition were challenges that permeated our insertion in the field, how we moved within it and the writing of these experiences, aligned with the ethical-political commitment to being there, experiencing and accompanying the deterritorialization-reterritorialization processes (Guattari \& Rolnik, 1986/2000) of the lives of people in situations of extreme precariousness, exclusion and violence and sharing other worlds with them. In other words, while the loss of references of space-time-bonds-feelings produces deep and sometimes irreversible ruptures, it is also capable of managing inventive ways of living and occupying urban spaces, which escape the guilt and victimization with which these people are identified.

Given this scenario, if we must on the one hand point to the conditions of economic, political and social domination that create precarious lives and systems of exclusion, it is on the other hand "equally necessary not to let such subjects and bodies, generally associated with this bare life condition (excluded, marginalized, sick, refugees) be reduced to it" (Frangella \& Rui, 2017, p. 33). Through this complex dynamic, we ask: how can the intersubjectivity created in this context of physical or symbolic violence be reported? How can pains and dilemmas in a confrontation with theory be recorded (with imagination) so that they are not lost in this dimension? The challenge of not trivializing violence and experience presupposes, as Monroy (2015) suggests, delicacy and consists in bringing to the writing, either through what has been said or silenced, these feelings or the moment that corresponds to violence.

It is these reflections around the act of researching as an affirmation of life, especially of precarious lives, that lead us to ethnocartograph (as a verb and not to ethnocartography as a noun) as an exercise, focusing on craftsmanship: the attempt to weave dialogues between distinct methodological fields - ethnography and cartography - which meet, mingle, and combine into a research practice. More than discussing the constitution of a possible new field of knowledge ethnocartography -, we were interested in discussing the experimentation of an investigative practice, made

Estudos de Psicologia, 24(1), janeiro a março de 2019, 54-64 
possible by overcoming boundaries between disciplines and fields of knowledge.

Finally, we draw attention to the interdisciplinary perspective, without which the compositions and dialogues proposed here would not be possible. The openness to dialogue within the internal diversities of psychology and anthropology in and between these fields allowed us to risk these compositions, calling for other ways of searching outside specific, restricted and rigid disciplinary "boxes", blurring these limits and pointing to the possibility of new investigative challenges in the hope that these reflections and experiments may also contribute to the training of future researchers and professionals in working with vulnerable groups.

\section{References}

Amorim, A. K.; Nobre, M.T.; Coutinho, A. F.; Gomes, F.E. (2017). Entre canteiros e nuvens, perigos e guarda-chuvas: A experiência de uma pesquisaintervenção com pessoas em situação de rua. Estudos de Psicologia, 22 (4), p. 389-400. https://dx.doi.org/10.22491/1678-4669.20170040

Barros, L. P., \& Kastrup, V. (2009). Cartografar é acompanhar processos. In E. Passos, V. Kastrup, \& L. Escóssia (Eds.), Pistas do método da cartografia: pesquisa-intervenção e produção de subjetividade (pp. 52-75). Porto Alegre: Sulina.

Bittencourt, J. B. M. (2011). Nas encruzilhadas da rebeldia: uma etnocartografia dos straightedges em São Paulo (Doctoral Thesis, Universidade Estadual de Campinas, Campinas, São Paulo). Retrieved from http://repositorio.unicamp.br/jspui/handle/REPOSIP/280147

Butler, J. (2015). Quadros de guerra: quando a vida é passível de luto? Rio de Janeiro: Civilização Brasileira.

Castel, R. (1997). A dinâmica dos processos de marginalização: da vulnerabilidade à desfiliação. Caderno $C R H, 10(26), 19-40$. doi: $10.9771 /$ ccrh.v10i26.18664

Castro, M. R. N. \& Castro, F. F. (2017). No emaranhado do Guamá: trajetos etnográficos numa feira de Belém. Porto Urbe (20) 1-12. Doi: https://doi.org/ 10.4000/ pontourbe.3404

Certeau, M. (2005). A invenção do cotidiano: as artes de fazer. Petrópolis: Vozes. (Original work published in 1984)

Coimbra, C. M. B. (1995). Os Caminhos de Lapassade e da Análise Institucional: uma empresa possível. Revista do Departamento de Psicologia da UFF, 7(1), 52-80.

Corazza, S. M. (2007). Labirintos da pesquisa, diante dos ferrolhos. In M. V. Costa (Ed.), Caminhos investigativos I (pp. 105-131). Rio de Janeiro: Lamparina.

De Lucca, D. (2016). Morte e vida nas ruas de São Paulo: a biopolítica vista do centro. In T. Rui, M. Martinez, \& G. Feltran. (Orgs), Nova face da vida nas ruas (pp.19-43). São Carlos: EdUFScar.

Decreto n. 7.053/2009 (2009, 23 de dezembro). Institui a Política Nacional para a População em Situação de Rua e seu Comitê Intersetorial de Acompanhamento e Monitoramento, e dá outras providências. Brasília, DF: Presidência da República. Retrieved from http://www. planalto.gov.br/ccivil_03/_Ato2007-2010/2009/Decreto/D7053.htm
Deleuze, G. (2003). Lógica do sentido. São Paulo: Perspectiva.

Fabian, J. (2014). Ethnography and intersubjectivity Loose ends. Hau: Journal of Ethnographic Theory, 4(1), 199-209. doi: 10.14318/hau4.1.008

Félix-Silva, A. V., Sales, R. C. M., \& Soares, G. P. (2016). Modos de viver e fazer arte de pessoas em situação de rua. Estudos de Psicologia, 21(1), 46-57. doi: 10.5935/1678-4669.20160006

Fortuna, C. (2018). Caminhar urbano e vivências imprevistas. Revista Brasileira de Sociologia, 6(13), 136-154. doi: 10.20336/rbs.262

Foucault, M. (2005). Em defesa da sociedade. São Paulo: Martins Fontes.

Foucault, M. (2006). Microfísica do poder. Rio de Janeiro: Edições Graal. (Original work published in 1981)

Frangella, S. M. (2010). Corpos urbanos errantes: uma etnografia da corporalidade de moradores de rua em São Paulo. São Paulo: Annablume, Fapesp.

Frangella, S. M., \& Rui, T. (2017). Corpos precários: apontamentos para a relação entre corpo e cidade. Revista de Ciências Sociais -Política e Trabalho, 1(34), 23-38. doi: 10.22478/ ufpb.1517-5901.2017v1n47.36734

Guattari, F., \& Rolnik, S. (2000). Micropolítica: cartografias do desejo. Petrópolis: Vozes. (Original work published in 1986)

Idelfonse, F. (2013). Sobre a etnografia. In M. Mendonça Filho \& M. A. Ferreri. (Eds.), Instituições e cotidiano: formas e intensidades no enfrentamento do comum (pp. 13-37). São Cristóvão: UFS.

Ingold, T. (2014). That's enough about ethnography! Hau: Journal of Ethnographic Theory, 4(1), 383-395. doi: 10.14318/hau4.1.021

Kastrup, V. (2007). O funcionamento da atenção no trabalho do cartógrafo. Psicologia \& Sociedade, 1(19), 15-22. doi: 10.1590/ S0102-71822007000100003

Lapassade, G. (2005). As microssociologias. Brasília: Liber Livro.

Laplantine, F. (2004). A descrição etnográfica. São Paulo: Terceira Margem.

Lévi-Straus, C. (1996). Tristes trópicos. São Paulo: Companhia das Letras. (Original work published in 1955)

Lima, T. S. (2013). O campo e a escrita: relações incertas. Revista de Antropologia da UFSCar, 5(2), 9-23. Retrieved from http://www.rau. ufscar.br/wp-content/uploads/2015/05/vol5no2_01.TaniaStolzeLima.pdf

Lourau, R. (1993). Análise institucional e prática de pesquisa. Rio de Janeiro: EdUERJ.

Malinowsky, B. (1978). Argonautas do Pacífico Ocidental. Coleção os Pensadores (Vol. 48) São Paulo: Abril Cultural.

Magnani, J. G. C. (2002). De perto e de dentro: notas para uma etnografia urbana. Revista Brasileira de Ciências Sociais, 17(49), 11-29. doi: 10.1590/S0102-69092002000200002

Mairesse, D. (2003). Cartografia: do método à arte de fazer pesquisa. In T. M. G. Fonseca \& P. Kirst (Orgs.), Cartografias e devires: a construção do presente (pp. 259-272). Porto Alegre: EdUFRGS.

Merleau-Ponty, M. (1980). De Mauss a Lévi-Strauss. Coleção os Pensadores (Vol. 67). São Paulo: Abril Cultural. (Original work published in 1960)

Monroy, S. (2015). De cara com a violência: um exercício de escrita etnográfica. Etnográfica [Online], 19(1). doi: 10.4000/etnografica.3874

Nobre, M. T, Moreno, N. S., Amorim, A. K. M. A. \& Souza, E. C. (2018). Narrativas de modos de vida na rua: histórias e percursos. Psicologia \& Sociedade, 30, e175636. https://dx.doi.org/ 10.1590/1807-0310/2018v30175636 
Ethnography, cartography, ethnomapping: dialogues and compositions in the field of research

Passos, E., \& Benevides, R. (2009). Por uma política da narratividade. In E. Passos, V. Kastrup, \& L. Escóssia (Eds.), Pistas do método da cartografia: pesquisa-intervenção e produção de subjetividade (pp.150-171). Porto Alegre: Sulina.

Passos, E., Kastrup, V., \& Escóssia, L. (2009). Pistas do método da cartografia: pesquisa-intervenção e produção de subjetividade. Porto Alegre: Sulina.

Peirano, M. (2002). Rituais como estratégia analítica e abordagem etnográfica.In: M. Peirano (Ed.), O dito e o feito (pp.7-14). Rio de Janeiro: Relume-Dumará.

Pina-Cabral, J. (2013). The two faces of mutuality: Contemporary themes in anthropology. Anthropological Quarterly, 86(1), 257-266. doi: 10.1353/ anq.2013.0010

Prado, K. (2012). Desnaturalizar. In T. M. G. Fonseca, M. L Nascimento, \& C. Maraschin (Orgs.), Pesquisar na diferença: um abecedário (p. 71). Porto Alegre: Sulina.

Revel, J. (2005). Michel Foucault: conceitos essenciais. São Carlos: Claraluz.

Rocha, M. L., \& Aguiar, K. F. (2003). Pesquisa-intervenção e a produção de novas análises. Psicologia: Ciência e Profissão, 23(4), 64-73. doi 10.1590/S1414-98932003000400010
Romagnoli, R. C. (2009). A cartografia e a relação pesquisa e vida. Psicologia \& Sociedade, 21(2), 166-173. doi: 10.1590/ S0102-71822009000200003

Rui, T. (2014). Nas tramas do crack - etnografia da abjeção. São Paulo: Terceiro Nome.

Sanjek, R. (1996). Ethnography. In B. Alan \& J. Spencer (Orgs.), Enciclopedia of Social and Cultural Anthropology (pp. 193-198). London and New York: Routledge.

Sato, L.; \& Souza, M.P.R. (2001). Contribuindo para desvelar a complexidade do cotidiano através da pesquisa etnográfica em Psicologia. Psicologia USP, 1(2), 29-47. doi: 10.1590/S0103-65642001000200003

Simoni, A. C. R., \& Mosschen, S. (2012). Outrar. In T. M. G. Fonseca, M. L. Nascimento, \& C. Maraschin (Orgs.), Pesquisar na diferença: um abecedário (pp.177-179). Porto Alegre: Sulina.

Vasconcelos, M. F. F., Melo, M. R., \& Souza Neto, E. A. (2018). Etnocartografar com olhos rebeldes: infantilando imagens com "A culpa é do Fidel". Interdisciplinar, 29, 207-223. Retrieved from https://seer.ufs.br/index.php/interdisciplinar/article/view/9633

Veiga-Neto, A. (1995). Crítica pós-estruturalista e educação. Porto Alegre: Sulina.

1. Simone Frangella's work is supported by Portuguese (national) funds through FCT - Fundação para a Ciência e a Tecnologia, I.P., in the context of the celebration of the program contract foreseen in the numbers 4,5 and 6 of article 23. of D.L. no. 57/2016 of 29 August, as amended by Law no. $57 / 2017$ of 19 July. After a long time working with homelessness, the author has widened the researches concerning mobilities, aiming recently at transnacional migrations and its symbolica and social dynamics. She is a researcher at Instituto de Ciências Sociais, Universidade de Lisboa, Av. Professor Aníbal de Bettencourt 9, 1600-189 Lisboa, Portugal.

2. The political organization of the National Movement of Homeless People began in 2004, following the massacre of a group of homeless people in Praça da Sé, in São Paulo, by police officers. One of the effects of this organizational process was the creation of a public policy for the homeless. For an in-depth discussion of the creation of this social movement and its impacts and developments, see De Lucca (2016).

3. The research was linked to the Scientific Initiation Scholarship Program of the Dean of Research of University Federal of Rio Grande do Norte (Propesq / UFRN), in which students participated in the course of Psychology, Social Work, Law, History and Social Sciences

Maria Teresa Nobre, doutora e pós-doutora em sociologia pela Universidade Federal do Ceará, é docente e pesquisadora no

Programa de Pós-Graduação em Psicologia da Universidade Federal do Rio Grande do Norte. Endereço para correspondência:

UFRN - Centro de Ciências Humanas, Letras e Artes -

Departamento de Psicologia, Campus Universitário BR-101 Lagoa Nova - Natal/RN - CEP 59072-970. Telefone: (84)33422236. E-mail: tlnobre@hotmail.com

Ana Karenina Arraes Amorim, doutora em psicologia social pela Universidade Federal do Rio Grande do Norte, é docente no Departamento de Psicologia e no Programa de Pós-Graduação da Universidade Federal do Rio Grande do Norte.

E-mail: akarraes@gmail.com

Simone Frangella, doutora em ciências sociais/antropologia pela

Universidade Estadual de Campinas (UNICAMP), pós-doutora em antropologia pelo Goldsmiths College/University of London e pelo Instituto de Ciências Sociais da Universidade de Lisboa - ICS/

UL, é investigadora auxiliar no Instituto de Ciências Sociais da Universidade de Lisboa - ICS/UL. E-mail: simone.frangella@ics.ul.pt

Received in 30.mar.19 Accepted in 08.out.19 Revised in 10.dez.19

Estudos de Psicologia, 24(1), janeiro a março de 2019, 54-64 